\title{
The effects of differences in water exchange on the productivity of glass eel stage in Anguilla bicolor bicolor culture
}

\author{
Eri Setiadi ${ }^{*}$, Adang Saputra ${ }^{1}$, Imam Taufik ${ }^{1}$ \\ ${ }^{1}$ Research Institute for Freshwater Aquaculture and Fisheries Extension, Bogor, West Java, Indonesia
}

\begin{abstract}
Eel, Anguilla bicolor bicolor has an economic value for export commodity. Eel farming has been developed both of home to industries scales. However, the main problem during the glass eel culture is the low survival rate, characterized by high mortality. This condition is related to the culture technique that has not been established yet, especially water quality management. The research aims to determine the best water exchange during the culture of the glass eel on the survival, growth, and blood glucose. The different percentages of water exchange as a treatment were followed A) control (without water exchange); B) $20 \%$ of water exchange; C) $40 \%$ of water exchange; and D) $60 \%$ of water exchange. The water exchange has affected the survival, growth, and blood glucose $(\mathrm{P}<0.05)$. The ammonia, nitrite, and nitrate values during the culture period showed that the control was higher compared to the others. The water exchange of $40 \%$ is suitable for glass eel stage culture to obtain the best survival and growth.
\end{abstract}

\section{Introduction}

Eel Anguilla bicolor bicolor has a wide distributed eel species that high demands for local and export markets. This species is very famous in Asia and Europe. The total of Anguilla $\mathrm{sp}$ in the world is 11 species. Five species exist in Indonesia, i.e., Anguilla bicolor bicolor, A. marmorata, A. borneensis, A. celebesensis, A. interiosis and A. nebulosa. All of these species are involved in the IUCN red list with criteria are $A$. bicolor (near threatened), $A$. marmorata (least concern), A. borneensis (vulnerable), A. celebesensis (near threatened), $A$. interiosis (deficient), and A. nebulosa (least concern) [1]. Eel, Anguilla bicolor bicolor is an export commodity market, especially in Japan, China, Taiwan, Korea, Germany, and Italy. Thus, Anguilla bicolor has potency for export [2].

The production of eel, Anguilla bicolor bicolor is unstable caused by high mortality occurs during the glass eel to elver stages culture both of small and large scales of eel

*Corresponding Author: erisetiadi@yahoo.com 
farming [3]. The survival rate of elver is meager with ranging from $0-20 \%$. The culture techniques have been applied in order to increase the production, such as enzyme activities [4], Optimization of salinity [5], water temperature [6], Water exchange for feeding rate [7], different feeding rate [8], and transportation of glass eel [9]. However, it is not yet reported that the water exchange is related to survival, growth, blood glucose (physiological), and water quality. Therefore, the study of water exchange is needed to evaluate to improve productivity.

Water quality as culture media is essential in aquaculture. The advantage of intensive culture is can increase production by feeding 100 artificial diets. Still, this culture technique's disadvantage is the high nitrogen compound in the water media due to the accumulation of uneaten feed, feces, and urine from cultural activities. Aquaculture waste is mainly characterized by high containing of nitrogen $(\mathrm{N})$ and phosphorus $(\mathrm{P})$ elements [10]. Waste of aquaculture intensive containing 62\% total ammonia nitrogen (TAN) and $40 \%$ total phosphate [11]. The high nitrogen and phosphorus concentration is derived from $20 \%$ uneaten fed, $10 \%$ feces, and $15 \%$ urine [12]. Nitrogen and phosphorus released into the water ranges from $62-73 \%(\mathrm{~N})$ and $55-70 \%(\mathrm{P})$ in the form of particulate or dissolve [13]. Water quality is out of the requirements for fish culture can cause low productivity such as survival, growth, and biomass [14]. The nitrogen compound in the water can be the form of ammonia $\left(\mathrm{NH}_{3}-\mathrm{N}\right)$, nitrate $\left(\mathrm{NO}_{3}-\mathrm{N}\right)$, and nitrite $\left(\mathrm{NO}_{2}-\mathrm{N}\right.$ where phosphorus in the form of orthophosphate $\left(\mathrm{PO}_{4}-\mathrm{P}\right)$ [15]. Ammonia and nitrite are very toxic for living aquatic environments such as fish [16]. Therefore, to keep water quality in the requirements condition for eel culture should be maintained by water exchange. Water exchange can keep water quality stable [8].

Blood glucose plays an essential role as an indicator of fish physiology, especially the stress response on grass carp fish [17]. Similar research has also been reported that the glucose level in fish is related to the stress response caused by some factors such as high stocking density [18], environmental disturbance [19], salinity [20], and pollutant of heavy metal [20]. Since blood glucose is often used for the stress response thus, the present experiment is also the blood glucose will be used as a parameter to describe the physiological response related to water exchange. This research aims to determine the suitability of water exchange level on survival, growth, glucose profile, and water quality of glass eel culture to increase productivity.

\section{Materials and methods}

The research of water exchange level on glass eel was carried out from June to August 2019 in the multi-species hatchery at Research Station for Environment Technology and Toxicology of Freshwater Aquaculture, Cibalagung, Bogor. West Java, Indonesia.

Twelve aquariums with a water volume of $100 \mathrm{~L}$ were used. A water heater and aeration installed each aquarium. The aquarium was filled with groundwater for $60 \mathrm{~L}$. The glass eel with the bodyweight of $0.13 \pm 0.02 \mathrm{~g}$ and $4.98 \pm 0.43 \mathrm{~cm}$ in total length were used. The stocking density of glass eels per aquarium was 5 glass eels/L $(\approx 300$ glass eels per aquarium). The eel was cultivated for 60 days. The feeding was given $5 \%$ of biomass 3 times a day (at 8:00, 12:00, and 16:00 clocks).

The differences in water exchange in this experiment were A) $0 \%$ (without water exchange); B) $20 \%$; C) $40 \%$; and D) $60 \%$. Each treatment consisted of triplicates. Water exchange was conducted every day, and it depended on the treatment. The parameters observed such as survival rate and absolute weight and length [22]. The formula of survival rate, absolute weight, and absolute length was as bellowed [22]. 
Survival rate (SR)

$$
S R=\frac{N t}{N o} x 100 \%
$$

where

$$
\begin{aligned}
& \mathrm{SR}=\text { Survival Rate }(\%) \\
& \mathrm{Nt}=\text { Number of fish at the end experiment (individu) } \\
& \mathrm{No}=\text { Number of fish at the initial of experiment (individu) }
\end{aligned}
$$

Absolute weight growth

$$
\mathrm{W}=\mathrm{Wt}-\mathrm{Wo}
$$

where

$$
\begin{aligned}
\mathrm{W} & =\text { Absolute weight growth }(\mathrm{g}) \\
\mathrm{Wt} & =\text { finally weight }(\mathrm{g}) \\
\mathrm{W}_{0} & =\text { initial weight }(\mathrm{g})
\end{aligned}
$$

Absolute length growth

$$
\mathrm{L}=\mathrm{Lt}-\mathrm{Lo}
$$

where

$$
\begin{array}{ll}
\mathrm{L} & =\text { Absolute length growth }(\mathrm{cm}) \\
\mathrm{Lt} & =\text { final length }(\mathrm{cm}) \\
\mathrm{L}_{0} & =\text { initial length }(\mathrm{cm})
\end{array}
$$

The blood glucose was measured at the end of the experiment following [23] methods. Water quality parameters, including dissolved oxygen (DO), $\mathrm{pH}$, and water temperature, were checked by a water checker. Total ammonia nitrogen (TAN), nitrite, nitrate, and phosphate were analyzed in the laboratory according to [24] methods.

Experimental design using completed randomized design with four treatments and three replicates were applied. One-way analysis of variants (ANOVA) and Duncan test as multiple comparisons test were performed. All data were analyzed using IBM SPSS Statistic version 20 software.

\section{Results}

The result of the survival rate of glass eel culture with different water exchanges can be seen in Figure. 1. The survival rate (Figure 1) of eel cultured at other water exchanges showed that the higher of water exchange would be followed by increasing in survival rate. The highest survival rate $(81.57 \pm 7.51 \%)$ was found at $60 \%$ water exchange then followed by $40 \%(80.01 \pm 5.29 \%), 20 \%(70.25 \pm 3.15 \%)$, and the lowest $(43.11 \pm 5.51 \%)$ at $0 \%$. Statistical analysis revealed that $0 \%$ of water exchange showed significantly different $(\mathrm{P}<0.05)$ compared to the 20,40 , and $60 \%$ survival rates. The $20 \%$ of water exchange was lower in survival rate compared to 40 and $60 \%(\mathrm{P}<0.05)$. This means that water exchanged affects the glass eel survival.

The result of absolute weight growth (Figure 2) of eel cultured at different water exchange showed that the complete weight increased with increasing the water exchange but relative constants between 40 . The absolute weight $(1.07 \pm 0.19 \mathrm{~g})$ found at $60 \%$ water exchange was the highest, followed by $40 \%(1.07 \pm 0.16 \mathrm{~g}), 20 \%(0.93 \pm 0.12 \mathrm{~g})$, and the lowest $(0.52 \pm 0.10 \mathrm{~g})$ found at $0 \%$. Statistical analysis revealed that water exchange $0 \%$ 
showed different compared to the other treatments in terms of absolute weight $(\mathrm{P}<0.05)$. The water exchange of $20 \%$ was also significant compared to 0,40 , and $60 \%(\mathrm{P}<0.05)$. This indicated that water exchange influenced absolute weight growth.

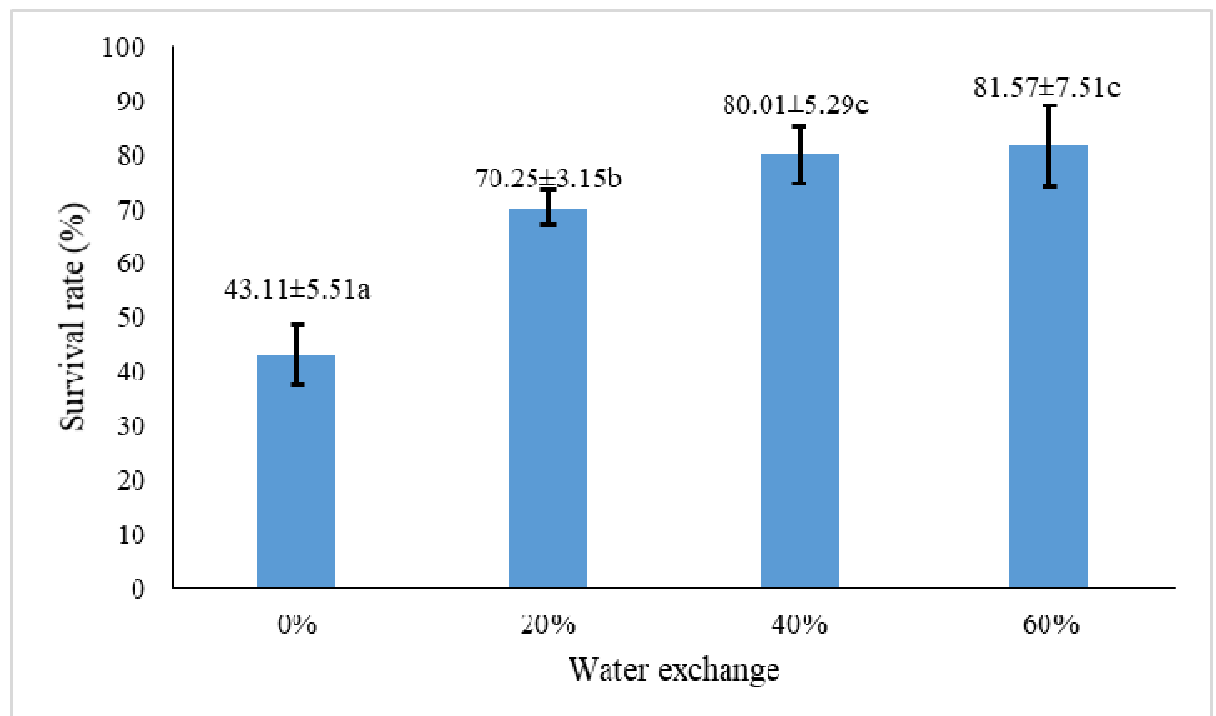

Fig. 1. The survival rate of glass eel. The bars following the same letters are not significantly different $(\mathrm{P}>0.05)$

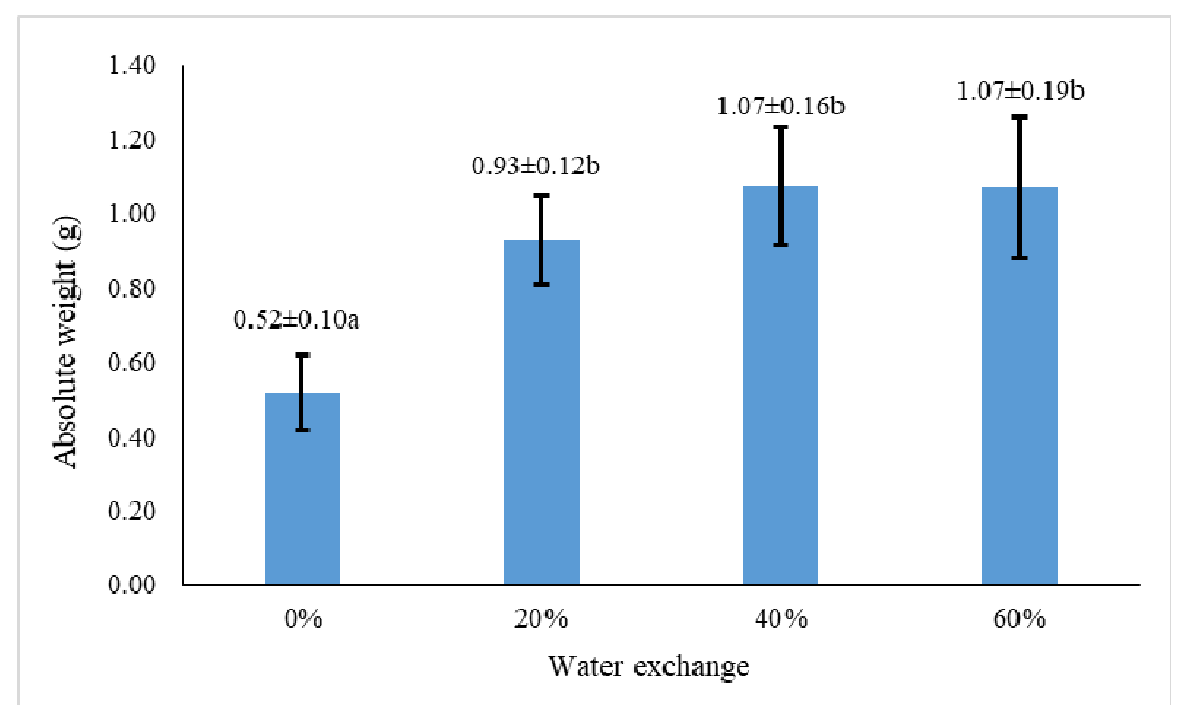

Fig. 2. The absolute weight of glass eel. The bars following the same letters are not different $(\mathrm{P}>0.05)$

The growth for absolute length (Figure 3) of glass eel cultured at different water exchange showed increased with increase in water exchange where the highest $(8.96 \pm$ $0.14 \mathrm{~cm}$ ) was found at $40 \%$ water exchange and $7.30 \pm 0.20 \mathrm{~cm}$ in absolute length found at $0 \%$. Statistical analysis revealed that water exchange of $0 \%$ was the lowest in absolute length compared to 20,40 , and $60 \%(\mathrm{P}<0.05)$. Therefore, it could be stated that the water exchange affected the absolute length. 


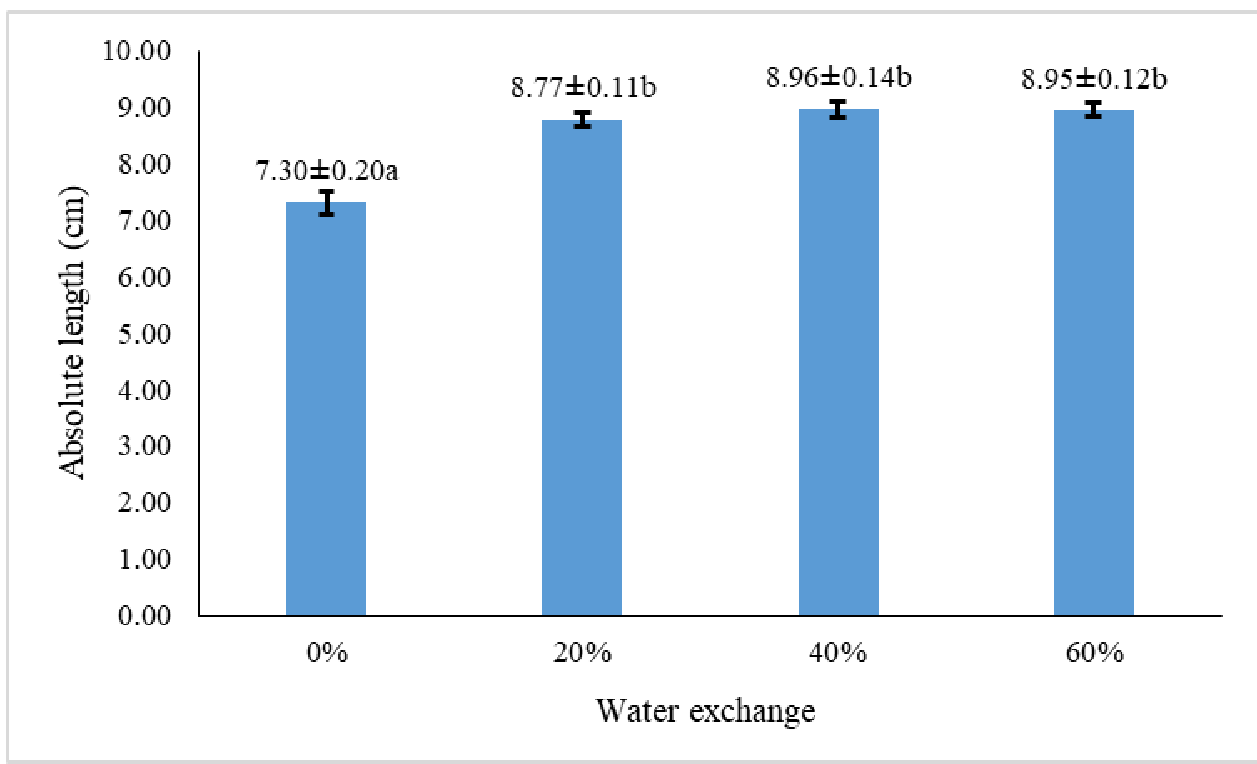

Fig. 3. The absolute weight of eel. The bars following the same letters are not different $(\mathrm{P}>0.05)$

The blood glucose of glass eel (Figure 4) showed that the value of blood glucose was increased with increasing the water exchange. The highest of blood glucose $(14.07 \pm 1.48$ $\mu \mathrm{g} / \mathrm{ml})$ found at $0 \%$, followed by $60 \%(6.28 \pm 1.69 \mu \mathrm{g} / \mathrm{ml}), 40 \%(2.45 \pm 0.15 \mu \mathrm{g} / \mathrm{ml})$, and the lowest $(0.27 \pm 0.15 \mu \mathrm{g} / \mathrm{ml})$ found at $20 \%$ of water exchange.

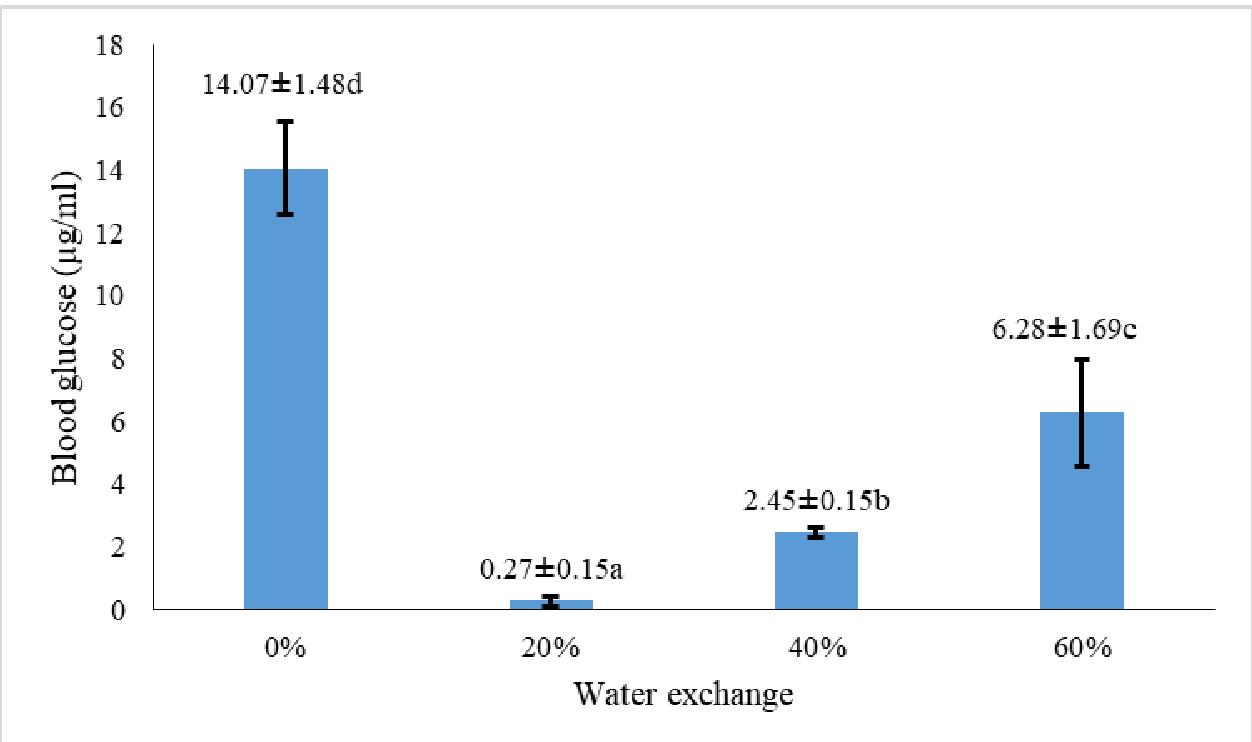

Fig. 4. The blood glucose of glass eel. The bars following the same letters are not different $(\mathrm{P}>0.05)$ 
The range of dissolved oxygen (DO), $\mathrm{pH}$, water temperature, total ammonia nitrogen (TAN), nitrite $\left(\mathrm{NO}_{2}-\mathrm{N}\right)$, and nitrate $\left(\mathrm{NO}_{3}-\mathrm{N}\right)$ on glass eel culture period (Table 1).

Table 1. The range of dissolved oxygen, $\mathrm{pH}$, water temperature, total ammonia nitrogen (TAN), nitrite, and glass eel culture

\begin{tabular}{|c|c|c|c|c|c|}
\hline \multirow{2}{*}{ Parameters } & \multirow{2}{*}{ Unit } & \multicolumn{4}{|c|}{ Water exchange (\%) } \\
\hline & & 0 & 20 & 40 & 60 \\
\hline $\begin{array}{l}\text { Water } \\
\text { Temperature }\end{array}$ & ${ }^{\circ} \mathrm{C}$ & $28.1-29.8$ & $28.3-29.6$ & $28.1-29.5$ & $28.2-29.7$ \\
\hline $\mathrm{pH}$ & & $7.22-7.53$ & $7.18-7.48$ & $7.20-7.51$ & $7.21-7.50$ \\
\hline DO & $\mathrm{mg} / 1$ & $2.51-4.86$ & $3.11-4.77$ & $3.16-4.78$ & $3.13-4.72$ \\
\hline TAN & $\mathrm{mg} / \mathrm{l}$ & $0.073-3.525$ & $0.080-1.005$ & $0.067-0.531$ & $0.075-0.452$ \\
\hline $\begin{array}{l}\text { Nitrite }\left(\mathrm{NO}_{2}-\right. \\
\mathrm{N})\end{array}$ & $\mathrm{mg} / \mathrm{l}$ & $0.04-0.25$ & $0.04-0.08$ & $0.03-0.07$ & $0.03-0.07$ \\
\hline $\begin{array}{l}\text { Nitrate }\left(\mathrm{NO}_{3}-\right. \\
\mathrm{N})\end{array}$ & $\mathrm{mg} / 1$ & $1.830-14.375$ & $2.404-6.585$ & $2.008-5.050$ & $2.085-4.656$ \\
\hline
\end{tabular}

Water quality parameters (Table 1) showed that temperature and $\mathrm{pH}$ at all treatments were the same values, except for the minimum concentration of dissolved oxygen (DO) at $0 \%$ water exchange was the lowest $(2.51 \mathrm{mg} / \mathrm{l})$ compared to the other treatments. The ranged of concentration of total ammonia nitrogen (TAN), nitrite $\left(\mathrm{NO}_{2}-\mathrm{N}\right)$, and nitrate $\left(\mathrm{NO}_{3}-\mathrm{N}\right)$ at $0 \%$ water exchange showed higher compared to the other treatments. It could be stated that water exchange could affect the water quality parameters, especially for the concentration of DO, TAN, nitrite, and nitrate.

\section{Discussion}

Water exchange contributes to fish survival on rainbow trout, Oncorhynchus mykiss [25]. The water exchange has increased or decreased in fish survival. This condition is caused by sudden environmental change if the high water exchange or event low of water exchange [26]. A similar result has also been reported regarding the optimal water exchange for tilapia culture within the middle exchange. Moreover, the high water exchange will lead to extreme environmental changes that affect fish physiology [27]. It has been known that water quality beyond the optimal condition for fish rearing can increase fish survival [28]. The present experiment shows that the higher water exchange level will be followed by an increase in survival (Figure 1). It suggests that the highest of water exchange at the present experiment has influenced the glass eel survival. However, the current research shows between 40 and $60 \%$ of water exchange do not differ on survival and growth (Figure 12 and 3 ). Thus, for the efficiency in water usage, $40 \%$ is better than that of $60 \%$.

The water exchange has influenced fish growth where the lower or higher water exchange can inhibit the catfish growth [26]. Otherwise, the increasing of water exchange has increased in fingerling eel growth [7]. The present experiment shows the discrepancy in terms of growth, where the increase of water exchange will not be led to increasing eel growth event seems to be relatively constant (Figure 2 and 3). It can be stated that the lower or even without water exchange can disturb fish growth. This may be caused by waste accumulation that influences the water quality. The waste concentration will increase following the culture period. Therefore, our result shows that the growth of glass eel culture at $0 \%$ water exchange is the lowest.

Blood glucose is described as the stress response of fish that results in the release of cortisol hormone on the hypothalamus via blood flow through the liver for breakdown of 
glycogen to glucose [29]. Fish in the stress condition can be seen as an increase the blood glucose value. Blood glucose will be used for homeostatic and decreasing insulin [30]. In the acute stress, fish has resulted in hyperglycemia will be led to reducing growth and low SGR. Even fish will be died on the following day [31]. The present experiment shows that the increase of water exchange has increased the blood glucose value and at $0 \%$, water exchange is the highest (Figure 4). This indicated that eel in the stress condition and the high mortality that occurs found at the $0 \%$ water exchange might be due to water quality (Table 1). Although the eel survival and growth are high at high water exchange, it does not guarantee that water exchange is suitable for the increased blood glucose value.

The maintaining of water quality during fish culture is the key to success for fish production. Water temperature, $\mathrm{pH}$, dissolved oxygen, ammonia, nitrite, and nitrate are critical in fish culture. Such water quality parameters that a direct effect on fish survival and growth. The main factor in intensive culture is the waste derived from uneaten feed, feces, and urine. This waste has resulted in an increase in nitrogen and phosphorus concentration in the water. Some nitrogen compounds, namely ammonia, and nitrite can inhibit fish growth and, in the high concentration, are very toxic to fish [16]. Our research shows that $\mathrm{DO}, \mathrm{pH}$, water temperature are relatively constant, except for total ammonia nitrogen, nitrite, and nitrate will increase (Table 1). This condition is caused by the accumulation of waste that will increase following the period of culture. The main contribution of garbage in an intensive culture is derived from uneaten fed, feces, and urine. It has been reported that $40-60 \%$ of nitrogen concentration in the water is derived from waste aquaculture activity, and this concentration will increase with the following culture period [14]. The present experiment shows that the water quality affects the glass eel survival (Figure 1), fish growth (Figure 2 and 3), and blood glucose (Figure 4). Therefore, water exchange is needed in order to keep the water quality stable.

\section{Conclusion}

The best water exchange for glass eel culture in order to support growth, survival, and efficiency on water usage is $40 \%$. The increasing of water exchange influences the increase in blood glucose related to stress conditions. The water exchange can keep the water quality which avoids the waste accumulated in the water as a media for glass eel culture.

\section{Acknowledgment}

We would like to thank Mr. Indra Heksa Nugraha as a technician, Ms Rani Rachmayani and Mr. Samsul as an analyst that supported from the beginning up to the end of the experiment, and also the other staff member of the Research Station for Environment Technology and Toxicology of Freshwater Aquaculture, Jalan Aria Surialaga no. 67, Cibalagung, Bogor, West Java. Indonesia.

\section{References}

1. M. J. Miller, J. Powell, K. Tsukamoto Zool Stud 48, 107 (2008)

2. R. Affandi J Iktiologi Indones. 5, 77-81 (2005)

3. F. N. Zulfikar. Undergraduate Thesis. Bandung (ID): Universitas Pendidikan Indonesia (2019)

4. I. Mulyani, R. Affandi, D. Iswantini, IOSR J. of Pharm 6, 6-11 (2016) 
5. A. Y. H. Lukas, D. Djokosetiyanto, T. Budiardi, A.O. Sudrajat, R. Affandi JAI 16, 215-222 (2017)

6. M. Luo, R. Guan, Z. Li, H. J. Aquaculture 400-401, 61-64 (2013)

7. N. Taufiq-Spj, S. Sunaryo, A. Wirasatriya, D.N. Sugianto IOP Conf. Ser. Earth and Environ. Sci. 55, 012-015 (2017)

8. L. Fekri, R. Affandi, T. Budiardi JAI 13, 21-27 (2014)

9. F. H. Taqwa, E. Supriyono, T. Budiardi, M. Setiawati, B. P. Utomo, R. Affandi OmniAkuatika, 14, 1-10 (2018)

10. R. Lazzari, B. Baldisserotto Bol Inst Pesca 34, 591-600 (2008)

11. J. A. S. Osti, M.A.B. Moraes, C.F. Carmo, C.T.J. Mercante Braz J. Biol. 78, 25-31 (2018)

12. C. Frid, M. Dobson Ecology of Aquatic Management (Prentice Hall, Pearson Education, Singapore, 2002)

13. Y. Yi, C. K. Lin, J. S. Diana, Eighteenth Annual Technical Report (Pond Dynamics/ Aquaculture CRSP, Oregon, 2001)

14. E. Setiadi, L. Setijaningsih, JAI 6, 107-122 (2011)

15. H. Effendi, Telaah Kualitas Air Bagi Pengelolaan Sumberdaya Lingkungan Perairan (Kanisius, Yogyakarta, Indonesia, 2003)

16. E. Voslarova, V. Pistekova, Z. Svobodova, I. Bedanova Acta Vet. BRNO 77, 445-460 (2008)

17. D. Jiang, Y. Wu, D. Huang, X. Ren, Y. Wang Fish Physiol Biochem 45, 1433-1442 (2017)

18. A. Widiyati, A. Saputra, E. Setiadi, JAI 14, 83-89 (2019)

19. D. M. Malini, Madihah, A.F. Apriliandri, S. Arista, IOP Conf. Ser. Earth and Environ. Sci 166 (2018)

20. W. C. Tsui, J.C. Chen, S.Y. Cheng, Fish Physiol Biochem 38, 1323-1329 (2012)

21. A. Afaghi, S. Zare, R. Heidari, Y. Asadpoor, R.M. Viayeh, Pak J Biol Sci 10, $1655-$ 1660 (2007)

22. M. I. Effendie, Fisheries Biology (in Bahasa Indonesia) (Yayasan Pustaka Nusantara, Yogyakarta, 2002)

23. S. C. Eames, L. H. Philipson, V. E. Prince, M. D. Kinkel Zebrafish. 7, 205-213 (2010)

24. SNI. Water and waste water test procedure for Total ammonia (TAN), Nitrite $\left(\mathrm{NO}_{2}-\mathrm{N}\right)$, and Nitrate $\left(\mathrm{NO}_{3}-\mathrm{N}\right)$ using spectrophotometer (in Bahasa Indonesia) (2005)

25. C. Good, J. Davidson, C. Welsh, B. Brazil, K. Snekvik, S. Summerfelt Aqua. 294, 8085 (2009)

26. A. O. Ajiboye, A. A. Awogbade, O.A. Babalola I, JLP 6, 57-60 (2015)

27. C. I. M. Martins, D. Ochola, S.S.W. Ende, Ep.H. Eding, J. A. J. Verreth Aquaculture 298, 43-50 (2009)

28. K. W. Hidayat, E. Supriyono, D. Djokosetiyanto, A. Widiyati, Int J. Fish Aquat. Stud 4, 170-172 (2016)

29. M. Martinez-Porchas, L. R. Martinez-Cordova, R. Ramos-Enriquez, Pan-Am. J. Aquat. Sci 4, 158-178 (2009)

30. F. Royan, S. Rejeki, A.H.C. Haditomo J. Applied Material and Technology 3, 109-117 (2014) 
31. A. Pederzoli, L. Mola Acta Histochem 118, 443-449 (2016) 